\title{
IDENTIFIKASI AKTIFIVITAS EKONOMI DAN NILAI EKONOMI SPASIAL DAS CILIWUNG
}

\author{
Identification of the Economic Activities and Spatial Economic Value of the Ciliwung \\ Watershed
}

\author{
Nur Aini ${ }^{\text {a }}$, Tridoyo Kusumastanto ${ }^{\text {bc }}$, Luky Adrianto ${ }^{\mathrm{d}}$, Agus Sadelie ${ }^{\mathrm{e}}$ \\ ${ }^{a}$ Sekolah Tinggi Ilmu Ekonomi Ahmad Dahlan Jakarta Jl. Ciputat Raya No.77, Cireundeu, Ciputat Tim., Kota \\ Tangerang Selatan, Daerah Khusus Ibukota Jakarta15419-aini.nur1969@gmail.com \\ ${ }^{b}$ Program Studi Ekonomi Sumberdaya Kelautan Tropika, Sekolah Pascasarjana, Kampus IPB Baranang Siang, \\ Institut Pertanian Bogor \\ ${ }^{c}$ Pusat Kajian Sumberdaya Pesisir dan Lautan (PKSPL), Kampus IPB Baranang Siang, Institut Pertanian Bogor \\ ${ }^{d}$ Departemen Manajemen Sumberdaya Perairan, Fakultas Perikanan dan Ilmu Kelautan,, Institut Pertanian Bogor, \\ Kampus IPB Darmaga, Bogor 16680 \\ ${ }^{e}$ Departemen Ekonomi Sumberdaya Alam dan Lingkungan, Fakultas Ekonomi dan Manajemen, Institut Pertanian \\ Bogor, Kampus IPB Darmaga, Bogor 16680
}

\begin{abstract}
The ecological, social and economic functions of the Ciliwung watershed are essentially to meet human needs, from primary to tertiary. The fulfillment of human needs occasionally contributes to the reduction of watershed ecological functions that result in flooding in Jakarta and declining ecological functions in the Jakarta Bay. Therefore, the study of the identification of economic activity and economic value spatially along the Ciliwung watershed needs to be done so as not to err in the management of the watershed in the future. This research uses survey method. Sampling using multi-stage sampling method. Spatial analysis of land use is done by using GIS by Arc / View method, economic value analysis is done with use value and non-use value. The use value approach uses a value-added production approach that is GDP of gross production of each sector of economy, non-use value using CVM approach by calculating WTP value. Percentage of Ciliwung Watershed cover: Forest 46.87 percent (Primary Forest 9.25 percent, Secondary Forest 25.25 percent, Plantation Forest 12.07 percent), Shrubs 0.62 percent, Plantation 1.06 percent, Dry Land Agriculture 9.68 percent, Rice Field 1.44 percent, Settlement 40.09 percent. Economic activity of The Downstream Ciliwung Watershed is dominated by the secondary sector (manufacturing, electricity, gas, water and construction). Economic activity of The Middle and Upstream Ciliwung Watershed is dominated by primary sector (Food crops, horticultural crops, plantation crops, Veterinary, Mining). The use value of Upstream Ciliwung Watershed is Rp 13.1 trillion, Middle Rp53.1 trillion and Downstream Rp1,117.6 trillion. Non-use value for the existence of The Upstream Ciliwung Watershed of Rp0.055 trillion, Rp 0.235 trillion of The Middlel and Downstream Rp0.657 trillion per year. The economic value of Upstream Ciliwung Watershed is Rp13.12 trillion, Midle Rp5.545 trillion and Downstream is Rp1,118.31 trillion.
\end{abstract}

Keywords: Economic activities, economics value, spatial watershed.

(Diterima: 03-05-2017; Disetujui: 18-09-2017)

\section{Pendahuluan}

\subsection{Latar Belakang}

Pergeseran kegiatan ekonomi masyarakat dari sektor pertanian ke sektor industri, perdagangan dan jasa telah terjadi secara nyata hampir di seluruh wilayah DAS. Beberapa penelitian melaporkan bahwa kegiatan ekonomi masyarakat di sekitar DAS mengakibatkan terjadinya degradasi dan alih fungsi lahan (Babier, 2004; McConnel et al., 2004; Wakeel et al., 2005).

Melihat perkembangan tingginya alih fungsi (konversi) lahan dan alih pemilikan lahan pada sebagian wilayah DAS, terutama DAS Ciliwung Hulu, ada kecenderungan yang sangat kuat bahwa kegiatan ekonomi berbasis lahan tidak dapat dipertahankan lagi (BPDAS Citarum Ciliwung, 2013). Perkembangan wilayah DAS Ciliwung Hulu yang telah sedemikian rupa karena faktor udara yang sejuk, kesuburan tanah yang baik serta lokasi yang strategis dilihat dari ibukota
Jakarta, Bogor, dan Bandung, telah mendorong proses komersialisasi lahan yang agresif (Suwarno, 2011).

Arus komersialisasi lahan yang semakin merebak membuat banyak masyarakat petani lokal yang tergiur melepaskan sebagian atau seluruh lahan miliknya kepada orang kota yang bermodal kuat. Pembelian lahan seperti itu jelas makin mempersempit lahan usaha tani masyarakat petani lokal (Ruspendi, 2014).

Pada kondisi tersebut, sebagian masyarakat mencari pekerjaan di sektor non-pertanian seperti menjadi tukang ojek sepeda motor, penjaga villa peristirahatan milik orang kota, karyawan rumah makan, padang golf, dan sebagainya. Sementara lahan yang telah mengalami perubahan kepemilikan (milik orang kota), biasanya akan segera mengalami konversi ke penggunaan lahan yang bersifat non-pertanian. Demikian pula status penguasaan lahan perorangan makin meningkat, sehingga lahan pertanian yang digarap masyarakat lokal dengan hak garap, terkonversi sesuai si pemilik lahan yang baru.

doi: 10.29244/jps1.8.2.223-234 
Fungsi sosial ekonomi DAS Ciliwung tak ubahnya seperti kawasan lainnya yang bisa digunakan untuk kepentingan apa saja demi memenuhi kebutuhan dasar manusia. Masyarakat di sekitar DAS Ciliwung masih memperlakukan wilayah sekitar Sungai Ciliwung sebagai "halaman belakang" (Suwarno, 2011). Secara kasat mata dapat dibuktikan dengan pembangunan rumah yang hampir semua membelakangi sungai. Belum lagi beragam pembangunan yang sedang bergeliat terus, baik perumahan, pertokoan dan infrasruktur publik lainnya yang jelas-jelas mengabaikan kawasan-kawasan strategis penyangga DAS Ciliwung.

Menurut Suwarno (2011), perekonomian DAS Ciliwung Hulu (khususnya), secara umum dipengaruhi oleh pemanfaatan jasa wisata dan pendapatan tambahan petani dari kegiatan non-pertanian. Pemanfaatan jasa lingkungan untuk kegiatan wisata, didukung oleh kondisi udara sejuk dan pemandangan Gunung GedePangrango.

Kondisi biofisik ini merupakan daya tarik wisatawan sehingga wilayah Puncak (DAS Ciliwung Hulu) berfungsi sebagai penyedia kebutuhan bagi masyarakat luas. Potensi demikian menjadikan daya tarik bagi warga sekitar Bogor, Jakarta dan sekitarnya untuk mengunjungi kawasan tersebut.

Kesadaran masyarakat tentang DAS Ciliwung Hulu yang masih kurang, juga menjadi satu persoalan yang tidak kalah penting. Kesadaran terbangun karena dari dua arah; internal dan ekternal. Secara internal semakin sulit ditemukan masyarakat di sekitar DAS Ciliwung Hulu yang memiliki inisiatif sendiri untuk menjaga dan merawat kawasan DAS Ciliwung Hulu sebagai kawsan strategis. Hal ini terlihat dari semakin masivnya konversi lahan pertanian dan sawah menjadi bangunan fisik. Secara ekternal kesadaran terbentuk karena pengaruh lingkungan dan pengetahuan yang masuk (Ruspendi, 2014).

Persoalan sosial di wilayah DAS Ciliwung Tengah dan Hilir, terlihat lebih kompleks dan berat. Penataan tata ruang pembangunan yang sejak awal tidak memberikan ruang bagi pengelolaan DAS Ciliwung Tengah dan Hilir. Akibatnya, persoalan DAS masih menjadi "anak tiri" pembangunan dan kebijakan tata ruang. Pembangunan lebih berorientasi pada kepentingan investasi pemodal. Salah orientasi pembangunan tata-ruang perkotaan inilah yang menjadi ciri khusus dari persoalan pengelolaan DAS Ciliwung di wilayah hilir (Ali, 2016).

Populasi penduduk di kawasan hilir yang terus meningkat menuntut fasilitas pendukung kehidupan. Sebagai pusat ibukota persoalan urbanisasi dalam beragam bentuknya menjadi masalah tersendiri seperti pencemaran dan banjir (Ali, 2016). DAS Ciliwung Hilir yang menjadi pusat pemerintahan dan ekonomi sekaligus semakin meningkatkan konversi kawasan strategis dan penyangga lainnya menjadi lahan bisnis dan pemukiman.
Persoalan yang tak kalah penting secara sosial adalah industrialisasi yang terus meningkat dan menyisakan limbah-limbah yang terus mencemarkan aliran sungai. Semakin meningkatnya peternakan yang ada di sepanjang DAS Ciliwung yang juga menyumbangkan pencemaran tersendiri. Persoalan konversi lahan untuk pembangunan dan industri menjadi simpul persoalan hulu hingga ke hilir DAS Ciliwung, sehingga semakin tidak tersisa lagi kawasan strategis dan penyangga DAS yang berakibat banjir di Ibukota Jakarta dan menurunnya fungsi ekologi dan ekonomi di perairan Teluk Jakarta (Ali, 2016).

Hal tersebut di atas merupakan satu pertanda bagaimana persoalan pengelolaan DAS belum terintegratif dan terkoordinatif antara wilayah hulu, tengah dan hilir serta antara sektor ekologi, sosial dan ekonomi (BPDAS Citarum Ciliwung, 2013). Pengelolaan wilayah DAS yang terpisah antara hulu tengah dan hilir menimbulkan berbagai persoalan (Pattanayak and Butry, 2005).

\subsection{Perumusan Masalah}

Berdasarkan latar belakang tersebut, maka peneliti mengungkapkan rumusan pertanyaan penelitian:

1. Bagaimana aktifivitas ekonomi secara spasial di DAS Ciliwung?

2. Berapa nilai ekonomi spasial DAS Ciliwung?

\subsection{Tujuan Penelitian}

Berdasarkan rumusan masalah tersebut, maka tujuan penelitian:

1. Mengidentifikasi aktifivitas ekonomi spasial DAS Ciliwung.

2. Menghitung nilai ekonomi spasial DAS Ciliwung

\section{Metodologi}

Penelitian ini adalah penelitian deskriptif. Penelitian deskriptif adalah salah satu jenis penelitian yang tujuannya untuk menghasilkan gambaran akurat tentang sebuah subjek penelitian (Nazir, 2005). Metode yang digunakan adalah metode survei. Metode survei digunakan untuk mengumpulkan data atau informasi tentang populasi yang besar dengan menggunakan sampel yang relatif kecil. Data dan informasi dapat diperoleh dari sampel, bukan dari populasi.

\subsection{Lokasi dan Waktu Penelitian}

Penelitian ini akan dilaksanakan di DAS Ciliwung dari hulu sampai hilir di Teluk Jakarta, mencakup Kabupaten Bogor, Kota Bogor, Kota Depok, Kota Jakarta Selatan, Kota Jakarta Timur, Kota Jakarta Pusat, Kota Jakarta Barat dan Kota Jakarta Utara. 


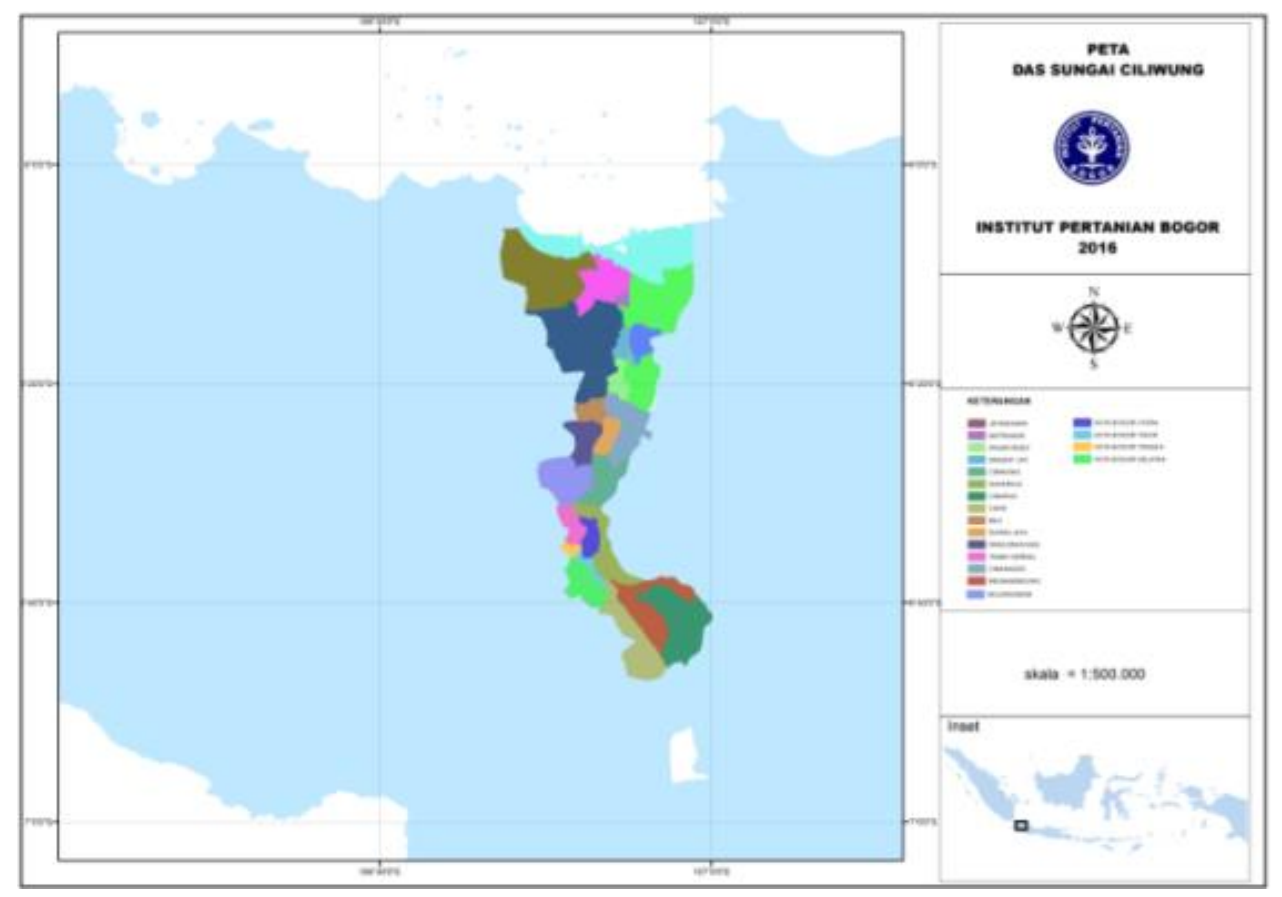

Gambar 1. Peta Lokasi Penelitian

Penelitian ini meliputi tahap prasurvei, survei, pengumpulan data baik data primer maupun data sekunder, pengolahan data, penyusunan draf hasil penelitian dan penyajian hasil penelitian. Penelitian dimulai dari Januari 2016 sampai April 2017.

\subsection{Jenis dan Sumber Data}

Jenis data yang dikumpulkan mencakup data primer dan data sekunder. Sumber data primer didapat dari wawancara penduduk dengan panduan kuisinoer sedangkan sumber data sekunder didapat dari BP DAS Citarum Ciliwung, LAPAN Pekayon Jakarta.

\subsection{Metode Pengumpulan Data}

Metode pengumpulan data dilakukan melalui pengumpulan data hasil kajian dan penelitian, pengamatan lapangan, wawancara, diskusi dan kuesioner. Responden lapangan diantaranya tokok masyarakat, petugas dan pakar dari instansi terkait.

Metode pengambilan sampel menggunakan metode multi-stage sampling. Metode multi-stage sampling adalah penggunaan berbagai metode random sampling secara berurutan. dengan seefisien dan seefektif mungkin (Nasir, 2005), yaitu dengan mengkluster berdasarkan kecamatan yang memiliki sebagian besar wilayahnya di tepi aliran Sungai Ciliwung dan kemudian menentukan sampel kecamatan berdasarkan representatif toposekuen DAS. Menurut Gay dan Diehl (1992), "sampel haruslah sebesar-besarnya". Pendapat ini mengasumsikan bahwa semakin banyak sampel yang diambil maka data akan semakin representatif dan hasilnya dapat digeneralisasi. Ia juga menjelaskan, ukuran sampelnya tergantung jenis penelitiannya. Penelitian deskriptif, sampel minimum adalah 10 persen dari populasi, maka diambil 8 kecamatan dari 50 kecamatan yang masuk dalam wilayah DAS Ciliwung.. Selanjutnya Malhotra (1993) memberikan panduan ukuran sampel yang diambil, dapat ditentukan dengan cara mengalikan jumlah variabel dengan 5, atau $5 \mathrm{x}$ jumlah variabel. Variabel yang ada di setiap toposekuen DAS Ciliwung adalah usia, tingkat pendidikan dan pendapatan. Maka setiap toposekuen DAS Ciliwung diambil 20 respondent, kecuali DAS Ciliwung Tengah 40 respondent. Berikut ringkasan jumlah sampel yang diwawancarai tiap spasial DAS Ciliwung.

Tabel 1. Ringkasan Jumlah Sampel Spasial DAS Ciliwung.

\begin{tabular}{lll}
\hline $\begin{array}{c}\text { Toposekuen DAS } \\
\text { Ciliwung }\end{array}$ & \multicolumn{1}{c}{ Kecamatan } & Jumlah Respondent \\
\hline Hulu & $\begin{array}{l}\text { Megamendung } \\
\text { Ciawi }\end{array}$ & 20 orang \\
\hline Tengah & $\begin{array}{l}\text { Bogor Timur } \\
\text { Bogor Tengah } \\
\text { Sukajaya } \\
\text { Cibinong }\end{array}$ & 40 orang \\
\hline Hilir & $\begin{array}{l}\text { Keramat Jati } \\
\text { Koja }\end{array}$ & 20 orang \\
\hline
\end{tabular}

\subsection{Metode Analisis Data}

\section{a. Analisis Identifikasi Aktivitas Ekonomi DAS Ciliwung}

Analisis spasial ini dilakukan dengan menggunakan SIG dengan metode Arc/View (Lynden dan Mantel, 2001). Jenis data yang dikumpulkan untuk identifikasi aktifitas ekonomi spasial DAS Ciliwung berdasaran tutupan lahan. Menurut Sriwongsitanon dan Taesombat (2011) dalam Ali (2016), klasifikasi penggunaan lahan DAS Ciliwung dibagi menjadi 6 kelas yaitu: (1) Hutan, (2) Semak/belukar, (3) Kebun campur/perkebunan teh, (4) Tegalan/ladang, (5) Sawah, (6) Pemukiman (termasuk jalan, lahan terbuka, dan lapangan). Data 
diambil dari data sekunder. Sumber data didapat dari Badan Penerbangan dan Antariksa Nasional dan BPDAS Citarum Ciliwung.

Sistem informasi geografis (SIG) merupakan teknologi informasi yang didefinisikan sebagai sistem informasi berbasis komputer yang dapat melakukan penyimpanan, perbaikan, manipulasi, transformasi, analisis dan penyajian data bereferensi geografis untuk mendukung pengambilan keputusan dalam perencanaan dan pengelolaan lahan, suberdaya alam dan lingkungan. Dalam SIG data disimpan dalam dua bentuk, yaitu: (1) data spasial, jenis data yang merepresentasikan aspek keruangan dari fenomena kebumian, (2) data atribut, jenis data yang merepresentasikan aspek dekskriptif dari fenomena yang dimodelkannya (Prahasta, 2002).

Penginderaan jauh merupakan ilmu dan seni pengukuran untuk mendapatkan informasi suatu objek atau fenomena. Ilmu ini menggunakan suatu alat perekaman dari suatu kejauhan, dimana pengukuran dilakukan tanpa melakukan kontak langsung secara fisik dengan objek atau fenomena yang diukur/diamati (Jaya, 2010). Informasi penginderaan jauh yang dihasilkan dari satelit image untuk analisis

Analisis penutupan lahan pada tahap ini adalah untuk identifikasi penutupan lahan pada daerah penelitian secara spasial kewilayahan. Data yang digunakan dalam tahap ini adalah Citra Landsat 8+ETM.

\section{b. Analisis Valuasi Ekonomi Spasial DAS Ciliwung}

Perhitungan nilai ekonomi yang dilakuan di DAS Ciliwung menggunakan use value dan non use value. Pendekatan use value menggunakan pendekatan nilai tambah produksi yaitu produk domestik regional bruto (PDRB). Nilai PDRB diperoleh dengan cara mengurangkan nilai out put yang dihasilkan oleh seluruh kegiatan ekonomi dengan biaya dari masingmasing nilai produksi bruto tiap sektor ekonomi (BPS, 2016). Sedangkan Non-Use Value pada nilai keberadaan DAS Ciliwung menggunakan pendekatan Contingent Valuation Method dengan cara menghitung nilai WTP.

WTP per individu dapat secara langsung (straight forward) diperoleh dari hasil perhitungan nilai tengah mengikuti formula (FAO, 2000), sebagai berikut:

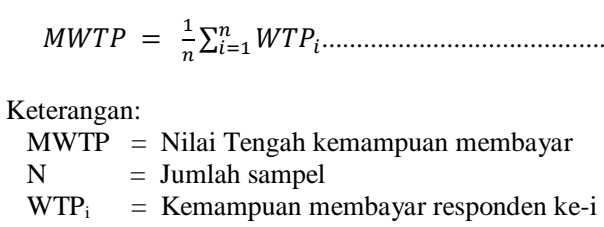

Estimasi $\mathrm{WTP}_{\mathrm{i}}$ dilakukan dengan menduga hubungan antara WTP dengan karakteristik responden yang mencerminkan tingkat penghargaan user terhadap sumberdaya yang selama ini dimanfaatkan, dengan menggunakan formula (Grigalunas and Congar, 1995), sebagai berikut:

$$
W T P_{i}=\beta_{0}+\sum_{i=1}^{n} \beta_{i} X_{i}
$$

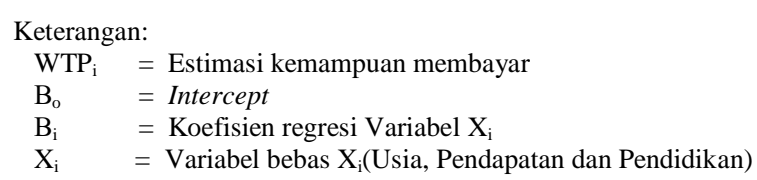

Total nilai ekonomi sumberdaya dilakukan dengan menggunakan formula.

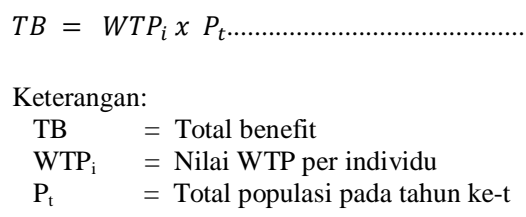

\section{Hasil dan Pembahasan}

\subsection{Sosial Ekonomi DAS Ciliwung}

Populasi penduduk di DAS Ciliwung hasil kajian studi, menunjukkan bahwa populasi penduduk di DAS Ciliwung Hulu lebih rendah 50 persen dari masingmasing penduduk di bagian Tengah dan Hilir. Semakin ke Hilir, populasi penduduk semakin tinggi. Populasi penduduk di DAS Ciliwung Hulu yaitu 630,026 jiwa, Tengah 2,481,778 jiwa, dan Hilir 5,914,831 jiwa. Populasi penduduk per kecamatan sebagaimana terlihat pada Gambar 5.

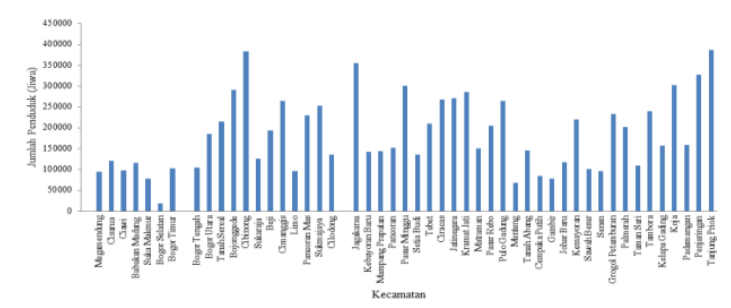

Sumber: BPS 2015-2016

Gambar 5. Jumlah Penduduk di DAS Ciliwung per Kecamatan 2014

Luas pemukiman hasil kajian studi, menunjukkkan luas lahan pemukiman di bagian Hulu yaitu 1,237.49 Ha, bagian Tengah 2,034.16 ha dan Hilir 17,818.36 ha. Berdasarkan kepadatan penduduk, makin ke hilir, kepadatan penduduk makin tingi. Kepadatan penduduk di DAS Ciliwung Hulu yaitu 12 jiwa per hektar, DAS Ciliwung Tengah 47 jiwa per hektar, dan DAS Ciliwung Hilir 112 jiwa per hektar. Kepadatan penduduk yang rendah di bagian Hulu tidak menyebabkan penduduk setempat memanfaatkan lahan menjadi optimal. Hal ini disebabkan tingkat kepemilikan lahan oleh masyarakat setempat hanya 2030 persen. Prosentasi kepemilikan lahan hingga 85 persen dikuasi oleh warga pendatang. Kondisi demikian menimbulkan permasalahan baru bagi masyarakat setempat seperti "lapar lahan". 


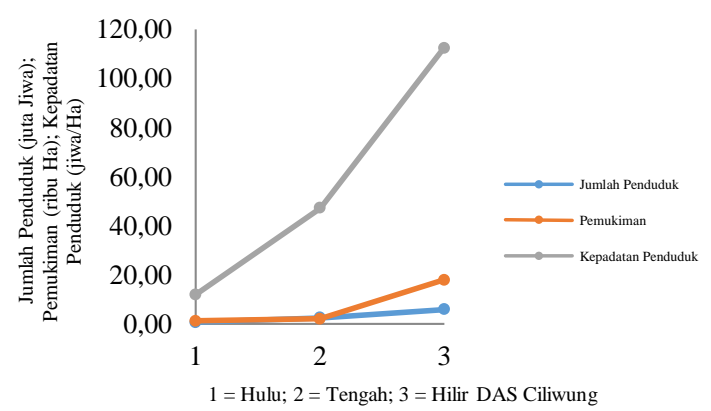

Gambar 6. Jumlah, Pemukiman dan Kepadatan Penduduk di DAS Ciliwung Hulu, Tengah dan Hilir 2014

Kondisi "lapar lahan" mengakibatkan tingginya tingkat penggarapan lahan oleh masyarakat di atas lahan milik masyarakat luar, penyerobotan dan penggarapan lahan hak guna usaha (HGU) dan eksHGU perkebunan maupun kawasan hutan. Kondisi demikian mendorong pendapatan masyarakat petani di wilayah ini semakin rendah dan cenderung miskin.

Kondisi sosial penduduk di DAS Ciliwung merujuk pada kajian Suwarno (2011) bahwa tingkat kondisi sosial masyarakat sekitar DAS Ciliwung adalah: (1) Rendahnya tingkat partisipasi masyarakat dalam pengambilan keputusan terhadap berbagai program seperti rehabilitasi hutan lahan (RHL), (2) Rendahnya persepsi masyarakat terhadap RHL, (3) Rendahnya pendidikan formal masyarakat lokal, (4) Rendahnya tingkat pendapatan masyarakat lokal dari bercocok tanaman pangan dan hortikultura, (5) Tingkat pertumbuhan penduduk yang tinggi.

Kompleksitas persoalan yang terjadi di masyarakat sekitar DAS Ciliwung seperti rendahnya pendapatan, semakin sempitnya lahan kepemilikan masyarakat dan tumpang tindihnya identitas lahan menjadi simpul persoalan sosial dalam pengelolaan DAS Ciliwung. Kondisi ketergantungan masyarakat pada lahan di wilayah DAS Ciliwung yang sangat beragam dan terus mengalami pergeseran sejalan dengan perkembangan wilayah Jakarta, Depok, dan Bogor. Pergeseran kegiatan ekonomi masyarakat dari sektor pertanian ke sektor industri, perdagangan dan jasa telah terjadi secara nyata hampir di seluruh wilayah DAS Ciliwung.

Kegiatan ekonomi masyarakat sekitar DAS Ciliwung pada sektor primer, dimana kegiatan usahanya tergantung pada lahan sudah semakin terbatas, yaitu pada wilayah DAS Ciliwung Hulu dan sebagian kecil wilayah DAS Ciliwung Tengah. Demikian pula jika melihat perkembangan tingginya alih fungsi (konversi) lahan dan alih pemilikan lahan pada wilayah ini ada kecenderungan yang sangat kuat bahwa kegiatan ekonomi berbasis lahan tidak dapat dipertahankan lagi.

Sebagaimana diketahui sejak 3 dekade terakhir khususnya kawasan puncak yang merupakan bagian dari wilayah DAS Ciliwung Hulu telah berkembang sedemikian rupa. Hal tersebut disebabkan antara lain karena faktor udara yang sejuk, kesuburan tanah yang baik serta lokasi yang strategis dilihat dari ibukota Jakarta, Bogor dan Bandung. Hal ini mendorong 227 proses komersialisasi lahan yang agresif. Penguasaan lahan perorangan makin meningkat menggantikan status lahan yang semula adalah hak garap dari masyarakat petani lokal.

Proses komersialisasi lahan yang semakin merebak ini menimbulkan banyak masyarakat petani lokal yang tergiur untuk melepaskan sebagian atau seluruh lahan miliknya kepada orang kota yang bermodal kuat. Pembelian lahan seperti itu jelas makin mempersempit lahan usahatani masyarakat petani lokal. Pada kondisi ini sebagian masyarakat mencari pekerjaan di sektor non-pertanian seperti menjadi tukang ojek sepeda motor, penjaga villa peristirahatan milik orang kota, karyawan rumah makan, padang golf, dan sebagainya.

Sementara lahan yang telah mengalami perubahan kepemilikan (milik orang kota), biasanya akan segera mengalami konversi ke penggunaan lahan yang bersifat non-pertanian. Hal ini akan menyumbangkan pengurangan penutupan vegetasi pada permukaan lahan yang penting untuk pemeliharaan fungsi wilayah DAS Ciliwung Hulu sebagai daerah tangkapan hujan.

Hubungan antar toposekuen DAS Ciliwung secara ekologi, sosial dan ekonomi menentukan keterkaitan pengelolaan DAS Ciliwung secara berkelanjutan. Dilihat dari proporsi penggunaan lahan, jumlah penduduk di DAS Ciliwung, serta perbedaan karakteristik dan PDRB antar toposekuen DAS, maka terlihat jelas bahwa telah terjadi ketimpangan pengelolaan.

Pengelolaan DAS di wilayah hilir dengan ciri sektor PDRB yang dominan adalah sektor sekunder bahkan tersier, sedangkan wilayah Tengah dan Hulu masih didominasi oleh sektor primer. Apabila ketimpangan yang ada tidak diperbaiki, akan mengakibatkan kesenjangan yang semakin lebar. Kesenjangan ini antara lain dapat menimbulkan banyaknya penduduk bermigrasi ke DAS Ciliwung Hilir.

Bermigrasi merupakan proses berpindahnya penduduk dari suatu tempat ke tempat lain melewati batas wilayah tertentu yang dilalui dalam perpindahan tersebut. Perpindahan yang melewati batas desa/kelurahan saja disebut sebagai migrasi antardesa/kelurahan. Perpindahan yang melewati batas kecamatan disebut migrasi antarkecamatan, yang melewati batas kabupaten/kota disebut migrasi antarkabupaten/kota, yang melewati batas provinsi disebut migrasi antarprovinsi. Penduduk yang melakukan perpindahan tersebut disebut dengan migran.

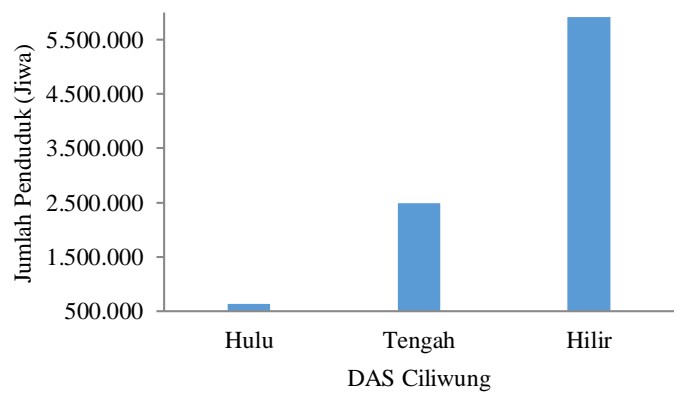

Gambar 7. Jumlah Penduduk di DAS Ciliwung Hulu, Tengah dan Hilir 2014 
Kemajuan ekonomi serta tingkat kesejahteraan ratarata penduduk di DAS Ciliwung Hilir, tinggi. Hal ini digambarkan oleh PDRB per kapita di Hilir yang jauh lebih tinggi dibandingkan dengan wilayah Tengah dan Hulu. Hal tersebut merupakan faktor penarik penduduk dari DAS Ciliwung Tengah dan Hulu bermigrasi ke DAS Ciliwung Hilir.

Sebaliknya arus migrasi penduduk dari DAS Ciliwung Hilir ke Tengah dan Hulu tahun 2012 yaitu 993.4 juta orang. Sedangkan migrasi penduduk DAS Ciliwung Tengah dan Hulu ke Hilir adalah 819.6 juta orang. Alasan perpindahan dari Hilir ke Tengah dan Hulu adalah masalah perumahan dan kenyamanan lingkungan serta sudah tersedianya sarana dan prasarana angkutan umum dan jaringan jalan tol yang sangat memadai.

\subsection{Tutupan Lahan DAS Ciliwung}

Berdasarkan analisis penggunaan lahan DAS Ciliwung, prosentase (1) Hutan 46.87 persen yang terbagi atas Hutan Primer 9,25 persen, Hutan Sekunder 25.25 persen dan Hutan Tanaman 12.07 persen, (2) Semak/belukar 0.62 persen, (3) Perkebunan 1.06 persen, (4) Pertanian Lahan Kering 9.68 persen, (5) Sawah 1,44 persen, (6) Pemukiman 40.09 persen. Luasan penggunaan lahan spasial DAS Ciliwung berdasaran toposekuen Hulu, Tengah dan Hilir dapat dilihat pada Tabel berikut.

Tabel 2. Tutupan Lahan Spasial DAS Ciliwung 2015

\begin{tabular}{|c|c|c|c|c|}
\hline \multirow[t]{2}{*}{ Tutupan Lahan } & \multicolumn{3}{|c|}{ Luas Spasial DAS (Ha) } & \multirow[t]{2}{*}{ Keseluruhan (Ha) } \\
\hline & Hulu & Tengah & Hilir & \\
\hline Hutan & 24657,79 & 0 & 0 & 24657,79 \\
\hline Pemukiman & 1237,49 & 2034,16 & 17818,36 & 21090,01 \\
\hline Pertanian & & & & \\
\hline Lahan Kering & 1465,91 & 2982,23 & 647,20 & 5095,34 \\
\hline Sawah & 0 & 756,44 & 0 & 756,44 \\
\hline Perkebunan & 555,91 & 0 & 0 & 555,91 \\
\hline Semak/Belukar & 328,70 & 0 & 0 & 328,70 \\
\hline Badan Air & 42,73 & 36,32 & 49,14 & 128,19 \\
\hline
\end{tabular}

Tutupan lahan berupa hutan hanya terdapat di DAS Ciliwung Hulu, sedangkan DAS Ciliwung Tengah dan Hilir sudah tidak mempunyai kawasan hutan sama sekali. Kawasan hutan yang ada di DAS Ciliwung Hulu merupakan hutan lindung yang berstatus hutan negara. Kawasan hutan ini didominasi oleh vegetasi hasil suksesi alami, namun kerapatan vegetasi pada hutan lindung tersebut makin lama makin berkurang. Pola penyebaran vegetasi hutan lindung, tidak merata, sehingga terdapat daerah gundul (tanah kosong) yang perlu segera direhabilitasi.

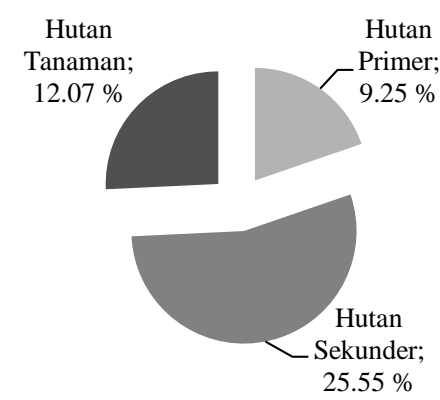

Gambar 2. Prosentase Jenis Tutupan Hutan di DAS Ciliwung Hulu 2015

Pola pemukiman di DAS Ciliwung Hulu, berbeda dengan pola yang ada di kawasan tengah. Pola pemukiman di DAS Ciliwung Hulu relatif menyebar, meskipun ada juga kecenderungan memusat ke arah sepanjang jalan raya Ciawi - Cisarua. Kawasan pemukiman di wilayah DAS Ciliwung Hulu tidak hanya berfungsi sebagai tempat tinggal penduduk lokal tapi pada beberapa kawasan DAS Ciliwung Hulu, pemukiman berfungsi sebagai tempat peristirahatan yang hanya dihuni pada saat-saat tertentu saja. Pada kawasan pemukiman penduduk yang pertama di atas, pemukiman masih mencerminkan tipe pemukiman pedesaan yaitu tempat tinggal yang digabung dengan kebun.

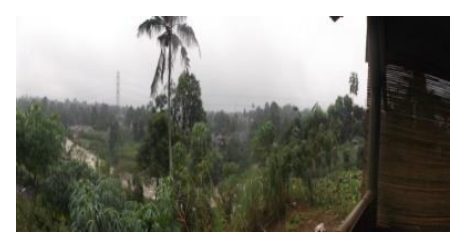

Gambar 3. Tipe Pemukiman Pedesaan di DAS Ciliwung Hulu

Sebaliknya tipe pemukiman DAS Ciliwung Tengah membentuk akumulasi-akumulasi hunian yang cenderung terpusat di Kota Bogor, Cibinong (sebagai Ibukota Kabupaten Bogor) dan di Kota Depok (sebagai pusat kota administatif terdekat dengan Jakarta). Pemukiman di kawasan tengah jauh lebih tertata dan memang berfungsi sebagai tempat tinggal. Selain untuk hunian, penggunaan lahan pemukiman di wilayah DAS Ciliwung Tengah juga banyak berubah fungsi menjadi kawasan industri dan kawasan perdagangan maupun perkantoran. Kawasan industri, perdagangan maupun perkantoran di DAS Ciliwung Tengah ini terakumulasi di sepanjang jalan Raya Bogor dan di sebagian pinggir Sungai Ciliwung. Terbangunnya industri di Ciliwung Tengah ini mempercepat terjadinya urbanisasi.

Pola pemukiman DAS Ciliwung Hilir membentuk akumulasi-akumulasi hunian di sepanjang tepian Sungai Ciliwung dengan kepadatan yang tinggi. Pemukiman dengan kepadatan yang tinggi ini umumnya merupakan bangunan perumahan perkampungan. Penataan pemukiman sangat berbeda antara perumahan perkampungan dengan perumahan 
real estate. Penataan pemukiman bagi perumahan real estate lebih tertata. Umumnya perumahan real estate dimiliki oleh penduduk pendatang.

Berdasarkan pola penggunaan lahan pemukimanan, dapat dikatakan bahwa DAS Ciliwung Tengah sudah mengalami proses urbanisasi dibandingkan dengan DAS Ciliwung Hulu. Pola penggunaan lahan di Ciliwung Hulu masih dapat dikatagorikan wilayah pertanian dengan fungsi khusus sebagai daerah pariwisata dan konservasi. Perkembangan di wilayah hulu ini dipercepat dengan adanya jalan tol Jagorawi hingga Gadok.

Tutupan lahan untuk penggunaan pertanian lahan kering, terluas ada di DAS Ciliwung Tengah yaitu 2,982.23 Ha. Kedua ada di DAS Ciliwung Hulu yaitu 1,465.91 Ha. Terakhir di DAS Ciliwung Hilir seluas $647.20 \mathrm{Ha}$. Prosentase penggunaan pertanian lahan kering dari total tutupan DAS Ciliwung adalah 9.68 persen. Tutupan lahan berupa hamparan sawah, hanya terdapat di DAS Ciliwung Tengah seluas 756.44 ha atau 1,44 persen dari tutupan lahan DAS Ciliwung keseluruhan. Komoditas yang dihasilkan yaitu padi, jagung, ubi kayu, ubi jalar, kacang tanah dan sayursayuran. Luasan lahan yang paling banyak digunakan adalah untuk menanam ubi kayu.

Tabel 3. Luas Lahan Garapan dan Produksi per Komoditas di DAS Ciliwung Tengah

\begin{tabular}{lcccccc}
\hline & \multicolumn{2}{c}{$\begin{array}{c}\text { Kabupaten } \\
\text { Bogor }\end{array}$} & \multicolumn{2}{c}{ Kota Bogor } & \multicolumn{2}{c}{ Kota Depok } \\
\cline { 2 - 8 } Komoditas & $\begin{array}{c}\text { Luas } \\
\text { (Ha) }\end{array}$ & $\begin{array}{c}\text { Produksi } \\
\text { (Ton) }\end{array}$ & $\begin{array}{c}\text { Luas } \\
\text { (Ha) }\end{array}$ & $\begin{array}{c}\text { Produksi } \\
\text { (Ton) }\end{array}$ & $\begin{array}{c}\text { Luas } \\
\text { (Ha) }\end{array}$ & $\begin{array}{c}\text { Produksi } \\
\text { (Ton) }\end{array}$ \\
\hline Padi sawah & 77 & 482 & - & - & 37 & 324,65 \\
Padi Gogo & 129 & 816 & - & - & & \\
Ubi Kayu & 384 & 8.037 & 294 & 3894 & 21 & 696,07 \\
Ubi Jalar & 9 & 128 & 96 & 2717 & 11 & 109,65 \\
Jagung & 20 & 292 & 170 & 2924 & 14 & 152,2 \\
Talas & 3 & 13 & 120 & 2625 & & \\
Kacang & 19 & 25 & 57 & 38 & 13 & 13 \\
Tanah & 19 & & & & &
\end{tabular}

Sumber: Dinas Pertanian dan Kehutanan Kab. Bogor 2016, Dinas Pertanian Kota Bogor 2016 dan Dinas Pertanian Kota Depok 2016

Produktivitas lahan untuk setiap komoditas berbedabeda. Produktivitas lahan tertinggi untuk komoditas padi 8,77 ton/ha dan ubi kayu 33,15 ton/ha, ada di Kota Depok, sedangkan ubi jalar 28,24 ton/ha, jagung 17,20 ton/ha dan talas 21,88 ton/ha ada di Kota Bogor, serta kacang tanah (1,32 ton/ha) ada di Kabupaten Bogor. Rata-rata produktivitas lahan sebesar 12,59 ton per hektar.

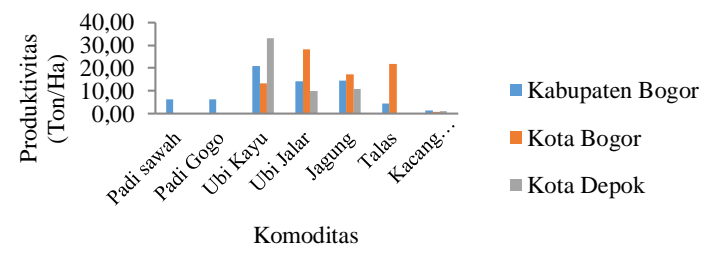

Gambar 4. Produktivitas Sawah dan Pertanian Lahan Kering di DAS Ciliwung per Komoditas.

\section{Use Value DAS Ciliwung}

Pendekatan ekonomi spasial DAS Ciliwung dalam kajian ini berbasis pemanfaatan (Use Value) dan nilai ekonomi berbasis bukan pemanfaatan (Non-Use Value). Use value menggunakan pendekatan nilai tambah produksi yaitu produk domestik regional bruto (PDRB). Nilai PDRB diperoleh dengan cara mengurangkan nilai out put yang dihasilkan oleh seluruh kegiatan ekonomi dengan biaya dari masingmasing nilai produksi bruto tiap sektor.

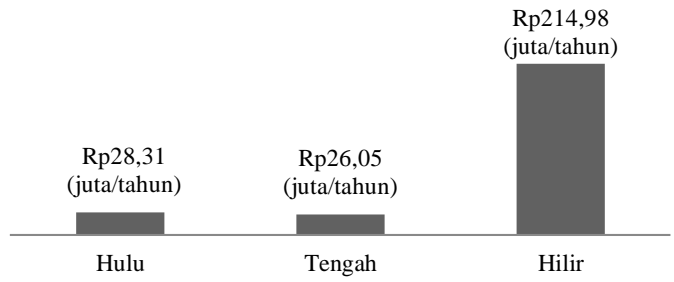

Gambar 8. PDRB per Kapita di DAS Ciliwung Hulu, Tengah dan Hilir 2014

Pendekatan use value melalui nilai PDRB mencakup seluruh struktur perkonomian per wilayah di sepanjang DAS Ciliwung 2015. Cakupan seluruh sektor ini saling terkait dalam membentuk gambaran perkonomian per wilayah kecamatan. PDRB tertinggi di DAS Ciliwung Hulu ada di Kecamatan Bogor Timur sebesar Rp. 2.9 triliun, DAS Ciliwung Tengah ada di Kecamatan Sukaraja sebesar Rp.10.6 triliun dan DAS Ciliwung Hilir ada di Kecamatan Kemayoran sebesar Rp. 103,7 triliun. PDRB per kecamatan di sepanjang DAS Ciliwung lebih lengkap dapat dilihat pada Gambar 9.

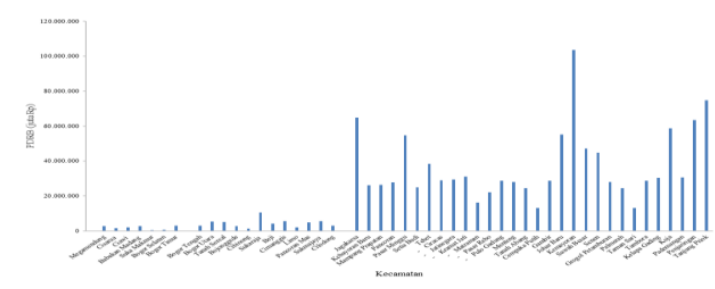

Sumber: BPS 2015-2016

Gambar 9. PDRB di DAS Ciliwung per Kecamatan

\section{a. Kecamatan Bogor Timur}

Kecamatan Bogor Timur berdasarkan peraturan pemerintah Nomor 2 Tahun 1995 dan Inmendagri No. 30 Tahun 1995 tanggal 24 Agustus 1995 tentang Perubahan Batas Wilayah Kotamadya Daerah Tk. II Bogor dan Kabupaten Daerah Tk. II Bogor, wilayah Kecamatan Bogor Timur dengan luas 1,015 Ha, terdiri dari dari 6 (enam) kelurahan $318 \mathrm{RT}$ dan $59 \mathrm{RW}$. Adapun kelurahan dimaksud adalah Kelurahan Sukasari, Kelurahan Katulampa, Kelurahan Tajur, Kelurahan Sindangsari dan Kelurahan Sindangrasa. Perbatasan Kecamatan Bogor Timur yaitu Kecamatan

Bogor Utara di sebelah Sebelah Utara, Kecamatan Sukaraja Kabupaten Bogor di sebelah Timur, 
Kecamatan Bogor Selatan dan Kecamatan Bogor Tengah di sebelah Barat, Kecamatan Ciawi Kabupaten Bogor di sebelah Selatan.

Kecamatan Bogor Timur memiliki misi antara lain untuk menata pusat-pusat perdagangan dan jasa serta kawasan permukiman yang tertib, tentram dan aman. Pemanfaatan semaksimal mungkin terhadap potensi yang dimiliki demi lancarnya penyelenggaraan pemerintahan, tercapainya peningkatan ekonomi dan pemberdayaan masyarakat

\section{b. Kecamatan Sukarata}

Sebagai kecamatan dengan PDRB tertinggi di DAS Ciliwung Tengah, Kecamatan Sukaraja memiliki beberapa potensi. Berdasarkan jarak orbitas, pusat pemerintahan Kecamatan Sukarata ke Ibukota Negara (Jakarta) yaitu $52 \mathrm{~km}$, Ibukota Provinsi (Bandung) yaitu $120 \mathrm{~km}$ dan ke Ibukota Kabupaten (Cibinong) yaitu $6 \mathrm{~km}$. Secara topografi, Kecamatan Sukaraja beriklim sedang dengan temperatur suhu rata-rata $32^{\circ} \mathrm{C}$, dengan ketinggian antara $200-750 \mathrm{mdpl}$, dan curah hujan rata-rata $300-3500 \mathrm{~mm}$ per tahun.

Secara geografis kecamatan sukaraja merupakan gerbang kabupaten bogor, karena berbatasan langsung dengan kota bogor. Akses jalan tol Jagorawi, memungkinkan Kecamatan Sukaraja dikembangkan sebagai pengembangan wilayah industri, pemukiman, agrowisata dan pertanian. Dengan letaknya yang sangat strategis tersebut, maka spesifikasi Kecamatan Sukaraja memerlukan pengembangan infrastruktur yang dapat memenuhi kebutuhan masyarakatnnya yang majemuk.

Bila dilihat dari karaktristik wilayah, kecamatan sukaraja merupakan wilayah permukiman, agrowisata pariwisata, industri dan pertanian. Kondisi tersebut dalam pengembangannya akan berpengaruh terhadap struktur sosial masyarakat yang bergeser dari pola hidup tradisional ke pola modern. Perubahan tersebut sedikit banyak akan berpengaruh kepada peningkatan Indeks Pembangunan Manusia (IPM) masyarakat secara tidak langsung, sehingga akan berpengaruh pula kepada peningkatan kesejahteraan masyarakat Kecamatan Sukaraja.

Berkenaan dengan pembangunan kualitas hidup penduduk Kecamatan Sukaraja, perkembangan kualitas sumberdaya manusia (SDM) menunjukkan kondisi yang semakin membaik. Hal tersebut antara lain ditunjukkan dengan pencapaian IPM yang dihitung berdasarkan tiga indikator, yaitu Indeks Pendidikan, Indeks Kesehatan dan Indeks Pembangunan.

Pada saat ini, peluang untuk meningkatkan kualitas sumber daya manusia melalui bidang pendidikan sangat terbuka. Hal ini ditopang oleh dukungan pemerintah baik pusat maupun daerah melalui APBNAPBD yang akan berupaya menyediakan anggaran untuk pendidikan sebesar 20 persen.

Dalam kaitan ini, pemerintah menyadari bahwa pendidikan merupakan salah satu sarana untuk meningkatkan kecerdasan dan keterampilan manusia, serta mempunyai andil besar terhadap kemajuan sosial ekonomi suatu bangsa. SDM yang berkualitas merupakan salah satu faktor penting bagi kemajuan bangsa. Semakin tinggi tingkat pendidikan masyarakat, maka semakin tinggi kualitas SDM di wilayah tersebut. Peluang untuk mendapatkan lapangan pekerjaan atau menciptakan peluang usaha lebih besar bagi mereka yang berpendidikan tinggi dibandingkan dengan mereka yang berpendidikan rendah.

\section{c. Kecamatan Kemayoran}

Kecamatan Kemayoran terkenal akan pusat perbelanjaannya. Wilayah Kecamatan Kemayoran terdapat beberapa macam pasar. Dua diantaranya yang menjadi pusat perhatian warga kemayoran ataupun warga lainnya adalah ITC Cempaka Mas yang terletak di Kelurahan Sumur Batu dan PRJ Kemayoran yang terletak di wilayah Kelurahan Kemayoran.

Jakarta Pusat menjadi salah satu tempat tujuan utama wisatawan baik domestik maupun mancanegara. Untuk menunjang tingginya tingkat kunjungan ke Jakarta Pusat khususnya Kecamatan Kemayoran sebagai pusat perbelanjaan dan perkantoran, diperlukan ketersediaan sarana akomodasi yang memadai. Sarana akomodasi tersebut antara lain hotel dan restoran. Di wilayah Kemayoran terdapat 12 pasar, 54 mini market, 23 restoran, 525 kedai dan 636 toko kelontong. Pada tahun 2014 di Kecamatan Kemayoran terdapat 3 hotel berbintang dan 19 hotel non bintang serta jumlah keseluruhan restoran dan rumah makan yang ada berjumlah 525 .

\subsection{Non-Use Value DAS Ciliwung}

Metode analisis yang digunakan dalam menghitung nilai Non-Use Value DAS Ciliwung adalah analisis Contingent valuation Method (CVM). CVM adalah metode survei untuk menyatakan tentang nilai atau harga dari penduduk terhadap komoditi yang tidak memiliki pasar, dalam hal ini nilai keberadaan DAS Ciliwung. Tujuan dari CVM untuk mengetahui keinginan membayar dari masyarakat, serta mengetahui keinginan menerima kerusakan suatu lingkungan (Fauzi, 2014). Salah satu alat analisis CVM adalah willingness to pay. Analisis WTP telah banyak digunakan untuk melakukan penilaian terhadap keberadaan dan perbaikan kualitas lingkungan di daerah aliran sungai (Pattanayak and Butry, 2005). Kesediaan membayar masyarakat untuk membayar nilai keberadaan DAS menggambarkan manfaat ekonomi dari keberadaan DAS Ciliwung.

\section{a. Pengaruh Usia terhadap Estimasi nilai WTP DAS Ciliwung Hulu, Tengah dan Hilir}

Usia responden di DAS Ciliwung Hulu yaitu antara 21 sampai 60 tahun. Berdasarkan analisis regresi diketahui bahwa variabel usia berpengaruh negatif terhadap besarnya WTP di DAS Ciliwung Hulu. Artinya bahwa kenaikan usia responden satu tahun di DAS Ciliwung Hulu, justeru menurunan nilai WTP 
sebesar Rp. 86.00. Rata-rata nilai WTP DAS Ciliwung Hulu adalah Rp.7250 per individu.

Usia responden di DAS Ciliwung Tengah yaitu antara 20 sampai 53 tahun. Variabel usia dari analisis regresi berpengaruh negatif terhadap besarnya WTP di DAS Ciliwung Tengah. Kenaikan usia responden di DAS Ciliwung Tengah, menurunkan nilai WTP sebesar Rp. 130.00. Rata-rata nilai WTP DAS Ciliwung Tengah adalah Rp. 7875 per individu.

Usia responden di DAS Ciliwung Hilir yaitu antara 21 sampai 55 tahun. Berdasarkan analisis regresi diketahui bahwa variabel usia juga berpengaruh negatif terhadap besarnya WTP di DAS Ciliwung Hilir. Artinya bahwa kenaikan usia responden satu tahun di DAS Ciliwung Hilir, juga menurunkan nilai WTP sebesar Rp. 129.00. Rata-rata nilai WTP DAS Ciliwung Hilir adalah Rp. 9250 per individu. Hal ini menunjukkan bahwa umur berpengaruh negatif terhadap kesediaan membayar masyarakat. Semakin tinggi tingkat usia responden maka semakin kecil kecenderungan peluang responden untuk bersedia membayar. Gambar regresi pengaruh usia menghasilkan estimasi model untuk nilai WTP dapat dilihat pada Gambar 10.

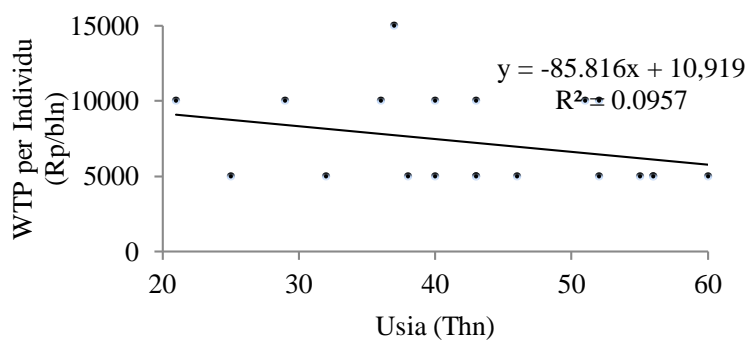

(a) Hulu

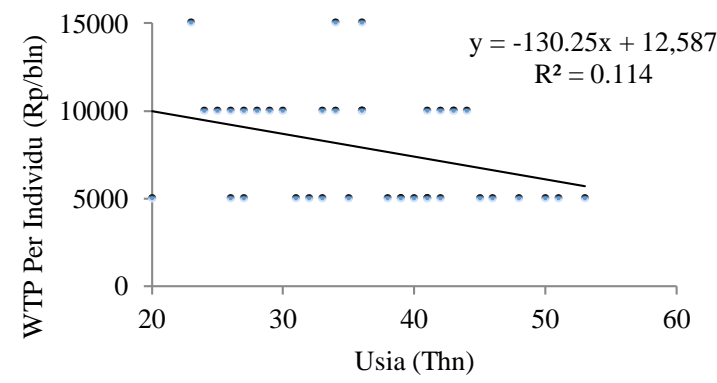

(b) Tengah

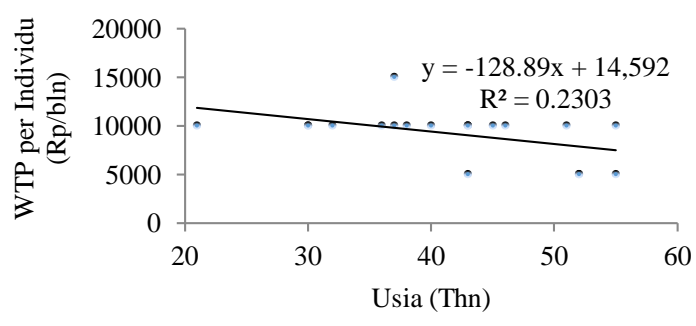

(c) Hilir

Gambar 10. Model Regresi Pengaruh Usia terhadap WTP Ciliwung

\section{b. Pengaruh Pendapatan terhadap Estimasi Nilai WTP DAS Ciliwung}

Berdasarkan analisis regresi diketahui bahwa variabel pendapatan berpengaruh berbeda-beda pada tiap toposekuen DAS Ciliwung. Pada DAS Ciliwung Hulu, Tengah dan Hilir, variabel pendapatan berpengaruh positif terhadap besarnya WTP. Kenaikan pendapatan per bulan, masing-masing menaikkan nilai WTP sebesar Rp0,0008,00; Rp0,0009,00 dan Rp0,0004,00. Variabel pendapatan sebagai variabel ekonomi, erat kaitannya dengan kemampuan ekonomi masyarakat dalam membayar nilai keberadaan DAS Ciliwung. Artinya semakin tinggi pendapatan responden maka semakin besar pula nilai WTP yang akan dibayarkan oleh responden tersebut. Herdiani (2009) dalam (Ladiyance dan Yuliana 2014) menunjukkan bahwa semakin tinggi pendapatan maka semakin tinggi kemampuan ekonominya sehingga semakin tinggi kemampuan dan kesempatan individu untuk dapat dan bersedia membayar nilai keberadaan lingkungan (DAS). Regresi pengaruh pendapatan menghasilkan estimasi model untuk nilai WTP DAS Ciliwung dapat dilihat pada Gambar 11.

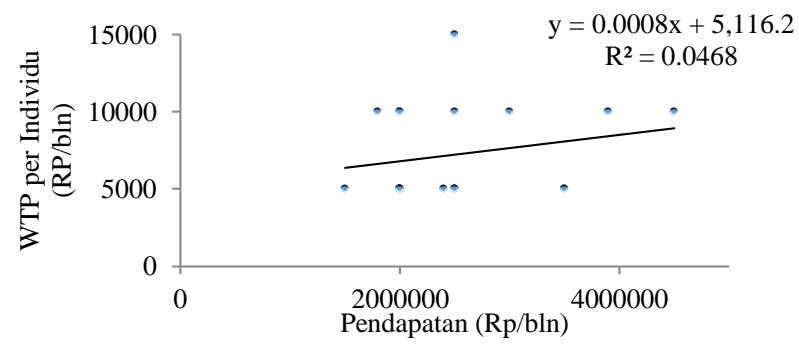

(d) Hulu

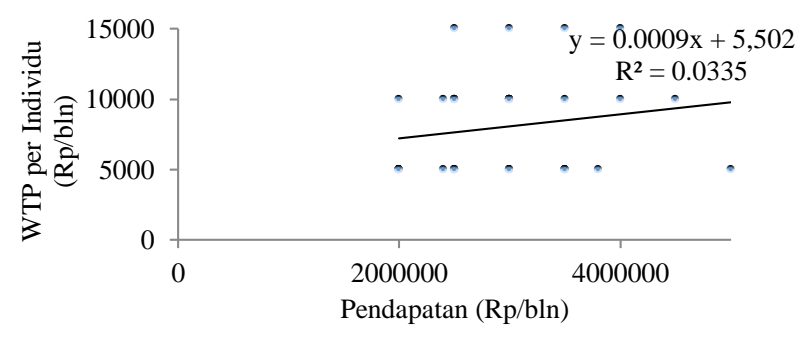

(e) Tengah

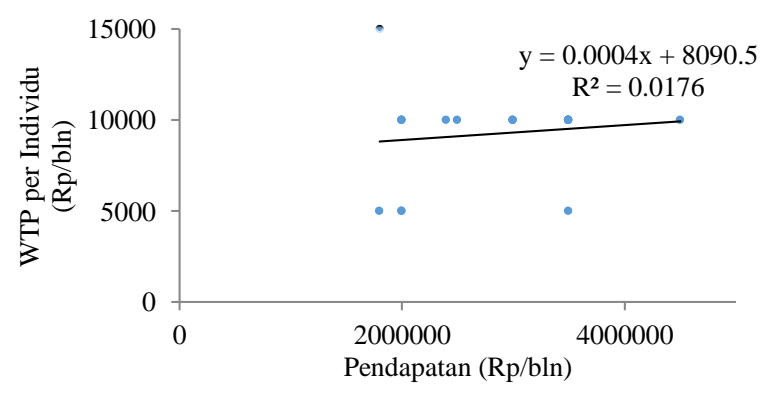

(f) Hilir

Gambar 11. Model Regresi Pengaruh Pendapatan terhadap WTP DAS Ciliwung Hulu, Tengah dan Hilir 


\section{c. Pengaruh Pendidikan terhadap Estimasi Nilai WTP DAS Ciliwung}

Pendidikan responden di DAS Ciliwung yaitu antara 6 sampai 16 tahun, dengan asumsi bahwa pendidikan 6 tahun (SD), 9 tahun (SMP), 12 tahun (SMA) dan 16 tahun (PT/S1). Prosentase responden yang berpendidikan SD dan SMP, masing-masing sebanyak 35 persen, SMA (25 persen) dan PT (1 persen). Berdasarkan analisis regresi diketahui bahwa variabel pendidikan berpengaruh positif terhadap besarnya WTP di DAS Ciliwung Hulu. Kenaikan pendidikan responden dari SD ke SMP dan seterusnya, menaikkan nilai WTP di DAS Ciliwung Hulu sebesar Rp. 145.00.

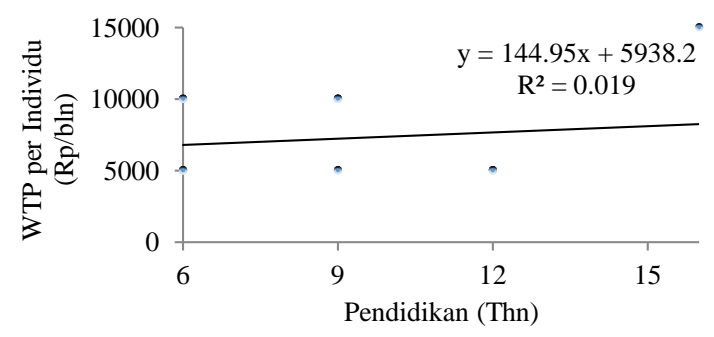

(g) Hulu

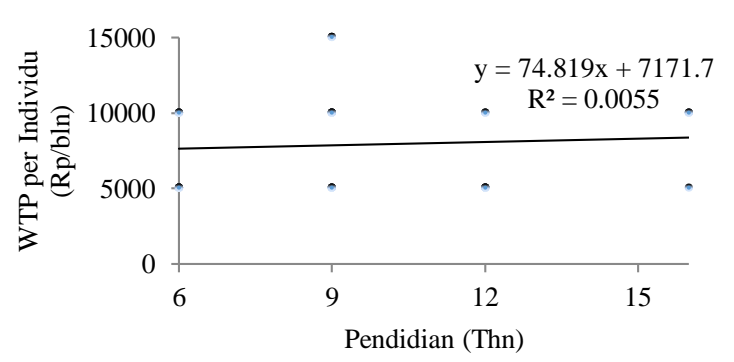

(h) Tengah

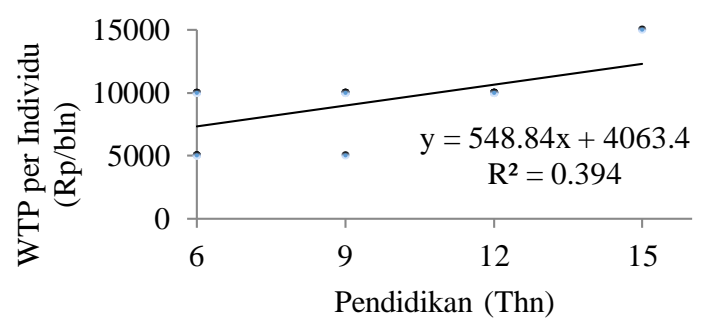

(i) Hilir

Gambar 12. Model Regresi Pengaruh Pendidikan terhadap WTP DAS Ciliwung Hulu, Tengah dan Hilir

Presentase pendidian responden di DAS Ciliwung Tengah terbanyak berpendidian SMP yaitu 35 persen. Selanjutnya berpendidikkan SD (32.5 persen), SMA (22.5 persen) dan PT (10 persen). Variabel pendidikkan dari analisis regresi berpengaruh positif terhadap besarnya WTP di DAS Ciliwung Tengah. Kenaikan tahap pendidikkan responden di DAS Ciliwung Tengah, menaikkan nilai WTP sebesar Rp75,00. Hasil kajian ini menunjukkan kenaikan pendidikkan responden satu tahap di DAS Ciliwung Hilir, menaikkan nilai WTP sebesar Rp. 549.00.
Prosentase pendidikan responden di DAS Ciliwung Hilir terbanyak yaitu berpendidikkan SMA (35 persen). Regresi pengaruh pendidikkan menghasilkan estimasi model untuk nilai WTP DAS Ciliwung dapat dilihat pada Gambar 12.

Berdasarkan analisis regresi diketahui bahwa variabel pendidikkan juga berpengaruh positif terhadap besarnya WTP di DAS Ciliwung Hilir. Hal ini menunjukkan bahwa responden yang memiliki tingkat pendidikan yang lebih tinggi memiliki kesediaan untuk membayar lebih tinggi untuk kualitas keberadaan DAS Ciliwung yang lebih baik. Simanjuntak (2009) dalam (Ladiyance dan Yuliana, 2014) menyatakan bahwa tingkat pendidikan sangat mempengaruhi pola pikir masyarakat terhadap sumber daya alam yang umumnya digunakan secara bebas dan tidak memerlukan biaya. Masyarakat dengan tingkat pendidikan lebih baik umumnya cenderung lebih memahami nilai ekonomi dari sumber daya yang semakin lama semakin terbatas jumlahnya dan menjadi barang ekonomi akibat kelangkaan yang terjadi.

Nilai WTP ini merupakan suatu pendekatan untuk mengetahui jumlah harga yang mampu dibayar oleh masyarakat atas keberadaan DAS Ciliwung. Nilai WTP merupakan nilai Non-Use Value atas keberadaan DAS Ciliwung. Secara spasial nilai Non-Use Value DAS Ciliwung Hulu, Tengah dan Hilir per tahun sebesar Rp. 0.055 Triliun; Rp. 0.235 Triliun dan Rp. 0.657 Triliun. Untuk lebih jelas dapat dilihat pada Tabel 4.

\begin{tabular}{|c|c|c|c|}
\hline & $\begin{array}{c}\text { WTP/Individu/Bln } \\
\text { (Rp) }\end{array}$ & $\begin{array}{c}\text { Jumlah } \\
\text { Penduduk } \\
\text { (Jiwa) }\end{array}$ & $\begin{array}{c}\text { WTP/Thn } \\
\text { (Rp } \\
\text { Triliun) } \\
\end{array}$ \\
\hline Hulu & 7250 & 630,026 & 0.055 \\
\hline Tengah & 7875 & $2,481,778$ & 0.235 \\
\hline Hilir & 9250 & $5,914,831$ & 0.657 \\
\hline
\end{tabular}

Nilai use value DAS Ciliwung Hulu yaitu Rp. 13.1 triliun, DAS Ciliwung Tengah Rp. 53.1 triliun dan DAS Ciliwung Hilir Rp. 1,117.6 triliun. Aktivitas perekonomian di DAS Ciliwung Hilir didominasi oleh sektor sekunder. Sektor sekunder mencakup industri pengolahan, listrik, gas, air bersih dan konstruksi. Dominannya aktivitas di sektor ini menunjukkan berkurangnya fungsi ekonomi pemanfaatan DAS Ciliwung Hilir dibandingkan di DAS Ciliwung Tengah dan Hulu. Sedangkan di DAS Ciliwung Tengah dan Hulu, sektor primer lebih mendominasi nilai PDRB. Sektor primer yang dimaksud mencakup sektor pertanian dan pertambangan.

Komoditas yang dihasilkan dari sektor primer adalah: Pertama, Tanaman pangan seperti padi, jagung dan ubi kayu; Kedua Tanaman hortukultura yang terdiri dari tanaman semusim (tanaman yang umumnya berumur pendek kurang dari 1 tahun dan hanya dipanen 1 kali untuk 1 kali penanaman) dan tanaman holtukultura tahunan (panen dilakukan satu atau beberapa kali untuk 1 kali penanaman). Komoditas yang dihasilkan meliputi sayur-sayuran, buah-buahan, tanaman biofarmaka dan tanaman hias; Ketiga, 
Tanaman perkebunan meliputi tanaman perkebunan semusim dan tanaman tahunan, baik yang diusahakan oleh rakyat maupun oleh perusahaan perkebunan (negara atau swasta). Komoditas yang dihasilkan seperti teh, kelapa sawit dsb.

Keempat, Peternakan dimulai dari usaha yang menyediakan pembibitan serta budidaya segala jenis ternak dengan tujuan untuk dikembangbiakkan, dibesarkan, dipotong, diambil hasil lainnya. Usaha peternakan ini dikelola rakyat maupun oleh perusahaan peternakan. Komoditas yang dihasilkan antara lain sapi potong, kerbau, kambing, domba, ayam buras, ayam ras (pedaging dan petelur), itik, susu dsb.

Tabel 5. Nilai Use Value, Non Use Value DAS Ciliwung Hulu, Tengah dan Hilir

\begin{tabular}{lcc}
\hline & $\begin{array}{c}\text { Use Value } \\
\text { (Rp Triliun) }\end{array}$ & $\begin{array}{c}\text { Non-Use Value } \\
\text { (Rp Triliun) }\end{array}$ \\
\hline Hulu & 13.065 & 0.055 \\
Tengah & 5.311 & 0.235 \\
Hilir & $1,117.654$ & 0.657 \\
\hline
\end{tabular}

Berdasarkan kajian ini terlihat nilai use value dan Non-Use Value di DAS Ciliwung masing-masing toposekuen dapat dilihat pada Tabel 5. Nilai ekonomi spasial DAS Ciliwung merupakan penjumlahan nilai use value dan non use value. Nilai ekonomi spasial DAS Ciliwung dapat dilihat pada Gambar 13.

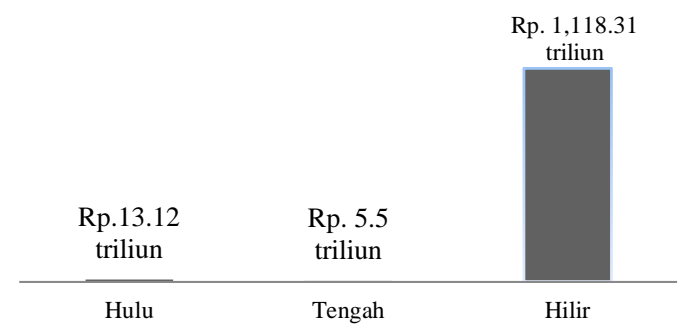

Gambar 13. Nilai Ekonomi Spasial DAS Ciliwung Hulu, Tengah dan Hilir Tahun 2015

Adanya perbedaan nilai nilai ekonomi yang sangat tajam antara DAS Ciliwung Hilir dengan DAS Ciliwung Tengah dan Hulu menunjukkan adanya perbedaan struktur kegiatan perekonomian. Hal ini disebabkan perbedaan teknologi produksi, keahlian sumberdaya manusia dan penggunaan input produksi (Solow, 1956) dalam hal ini penggunaan lahan. Selanjutnya berimplikasi pada fungsi DAS Ciliwung secara ekologi, sosial dan ekonomi.

\section{Kesimpulan}

Berdasarkan hasil penelitian sebagaimana telah dibahas, maka dapat disimpulkan bahwa:

1. Aktivitas perekonomian di DAS Ciliwung Hulu dan Tengah, didominasi oleh sektor primer. Sektor primer yang dimaksud mencakup sektor pertanian dan pertambangan. Komoditas yang dihasilkan dari sektor primer adalah: (1) Tanaman pangan antara lain padi, jagung dan ubi kayu; (2) Tanaman hortukultura antara lain sayur-sayuran, buahbuahan, tanaman biofarmaka dan tanaman hias; (3)
Tanaman perkebunan antara lain teh dan kelapa sawit; (4) Peternakan antara lain sapi potong, kerbau, kambing, domba, ayam buras, ayam ras, itik, susu termasuk usaha yang menyediakan pembibitan hingga panen; (5) Pertambangan antara lain galian tipe $\mathrm{C}$ (pasir kali). Aktivitas perekonomian di DAS Ciliwung Hilir didominasi oleh sektor sekunder. Sektor sekunder mencakup industri pengolahan, listrik, gas, air bersih dan konstruksi.

2. Nilai use value DAS Ciliwung Hulu yaitu Rp13,1 triliun, DAS Ciliwung Tengah Rp53,1 triliun dan DAS Ciliwung Hilir Rp1.117,6 triliun. Nilai NonUse Value atas keberadaan DAS Ciliwung Hulu yaitu Rp0,055 triliun; DAS Ciliwung Tengah Rp 0,235 triliun dan DAS Ciliwung Hilir Rp0,657 triliun. Nilai ekonomi DAS Ciliwung Hulu yaitu Rp13,12 triliun, DAS Ciliwung Tengah Rp5,545 triliun dan DAS Ciliwung Hilir Rp1.118,31 triliun.

\section{Daftar Pustaka}

[1] Ali, M., 2016. Kajian Dampak Perubahan Penutupan Lahan terhadap Kejadian Banjir pada Lanskap DAS Ciliwung Hilir dengan Pendekatan Sistem Dinamik. Tesis. Sekolah Pascasarjana. Institut Pertanian Bogor, Bogor.

[2] Barbier, E.B., 2004. Explaining Agricultural Land Expansion and Deforestation in Developing Countries. American Journal Economics No. 5, pp.1347-1353.

[3] BPDAS Citarum Ciliwung, 2013. Laporan Rencana Pengelolaan DAS (RPDAS) Terpadu DAS Ciliwung. Kementerian Kehutanan Direktorat Jenderal Bina Pengelolaan DAS dan Perhutanan Sosial Balai Pengelolaan Daerah Aliran Sungai Citarum-Ciliwung, Bogor.

[4] BPS, 2016. DKI Dalam Angka

[5] BPS, 2016. Kabupaten Bogor Dalam Angka

[6] BPS, 2016. Kota Bogor Dalam Angka

[7] BPS, 2016. Kota Depok Dalam Angka

[8] FAO, 2000. Application of Contingent Valuation Method in Developing Countries. FAO Economic and Social Development Papers No. 146/200. FAO, Rome

[9] Fauzi, A., 2014. Valuasi Ekonomi dan Penilaian Kerusakan Sumberdaya Alam dan Lingkungan: Berbagai Informasi Terkait Valuasi Ekonomi Disajikan dengan Dasar Teori yang Kuat dan Metode serta Contoh-Contoh Aplikasinya. IPB Press. Bogor.

[10] Gay, L.R., P.L. Diehl, 1992. Research Methods for Business and Management. MacMillan Publishing Company, New York.

[11] Grigalunas, T.A., R. Congar, 1995. Environmental Economics for Integrated Coastal Area Management: Valuation Methods and Policy Instruments. UNEP Regional Seas Reports and Studies No. 164. ENEP.

[12] Jaya, S.H.I., 2010. Analisis Citra Digital, Teori dan Praktik Menggunakan Erdas Imagine. Fakultas Kehutanan, Institut Pertanian Bogor, Bogor.

[13] Lynden, G.W.J., S. Mantel, 2001. The role of GIS and Remote Sensing in Land Degradation Assessment and Consevation Mapping: Some User Experiences and Expectations. JAG 3, pp. 61-68.

[14] Malhotra, N.K., 1993. Marketing Research and Applied Orientation. Prentice Hall International, USA. 
[15] McConnell, W.J., S.P. Sweeney, B. Mulley, 2004, Physical and Social Access to Land: Spatio-temporal Patterns of Agricultural Expansion in Madagascar. Journal Agriculture, Ecosystems and Environment No.101, pp.171-184.

[16] Nazir, M., 2005. Metode Penelitian. Ghalia Indonesia. Jakarta.

[17] Pattanayak, S.K., D.T. Butry, 2005. Spatial Complementarity of Forests and Farms: Accounting for Ecosystem Services. American Journal of Agricultural Economics. 87(4), pp. 9951008.

[18] Prahasta, E., 2002. Konsep-konsep Dasar Sistem Informasi Geografis. CV Informatika, Bandung.
[19] Ruspendi, D., 2014. Kajian Perubahan Penutupan Lahan pada DAS Ciliwung Hulu dengan Pendekatan Spasial Dinamik. Tesis. Sekolah Pascasarjana, Institut Pertanian Bogor, Bogor.

[20] Solow, R.M., 1956. A Contribution to the Theory of Economic Growth. The Quarterly Journal of Economics. 70(1), pp. 6594.

[21] Suwarno, J., 2011. Pengembangan Pengelolaan Berkelanjutan Das Ciliwung Hulu Kabupaten Bogor. Disertasi. Sekolah Pascasarjana, Institut Pertanian Bogor, Bogor. 